Table 1 Rate of reduction of the weight average, single-strand molecular weight of calf thymus DNA, and of poly(rA), at $50^{\circ} \mathrm{C}$ and $80^{\circ} \mathrm{C}, p \mathrm{H} \mathrm{7.0,}$, with and without $2 \mathrm{Zn}$ per nucleotide residue

\begin{tabular}{|c|c|c|c|c|c|c|}
\hline \multirow[b]{3}{*}{$\begin{array}{l}\text { DNA } \\
50^{\circ} \mathrm{C} \\
80^{\circ} \mathrm{C} \\
\text { Poly }\end{array}$} & \multicolumn{2}{|c|}{$\begin{array}{c}\text { Slope }\left(\mathrm{h}^{-1}\right) \text { of } M_{0} / M_{\mathrm{r}} \\
\text { against } \mathrm{t}^{*}\end{array}$} & \multicolumn{4}{|c|}{$\begin{array}{l}\text { Approximate time (h) for } \\
\text { reduction of } M_{0}+\end{array}$} \\
\hline & $+\mathbf{Z n}$ & $-\mathrm{Zn}$ & $\begin{array}{l}\text { to } 1 / \\
+\mathrm{Zn}\end{array}$ & & $\begin{array}{l}\text { to } 1 / 1 \\
+\mathrm{Zn}\end{array}$ & $\begin{array}{l}0 M_{0} \\
-\mathrm{Zn}_{\mathrm{n}}\end{array}$ \\
\hline & $\begin{array}{c}0.016 \pm 0.002 \\
2.1 \pm 0.6 \\
\text { A) }\end{array}$ & $\begin{aligned} & 0.014 \pm 0.003 \\
& 1.6 \pm 0.2\end{aligned}$ & $\begin{array}{c}62 \\
0.48\end{array}$ & $\begin{array}{c}71 \\
0.62\end{array}$ & $\begin{array}{l}560 \\
4.3\end{array}$ & $\begin{array}{l}640 \\
5.6\end{array}$ \\
\hline $\begin{array}{l}50^{\circ} \mathrm{C} \\
80^{\circ} \mathrm{C}\end{array}$ & $\begin{array}{c}72 \pm 4 \\
1,400 \pm 400\end{array}$ & $\begin{array}{l}0.20 \pm 0.04 \\
6.2 \pm 0.6\end{array}$ & $\begin{array}{l}0.014 \\
0.00064\end{array}$ & $\begin{array}{l}5.0 \\
0.16\end{array}$ & $\begin{array}{l}0.12 \\
0.0062\end{array}$ & $\begin{array}{r}45 \\
1.4\end{array}$ \\
\hline
\end{tabular}

* Evaluated from the plots of Fig. 1 (the mean deviation for fit to the experimental points are appended). $M_{0}$, initial weight average molecular weight; $M_{t}$, values at times $t$.

$\dagger$ Calculated from the slope of $M_{0} / M_{t}$ against $t ; M_{0} / M_{t}=$ $1+$ (slope)t

ions is generally unlikely during in vitro manipulations of DNA, although it must be taken into account with polyribonucleotides. Figure 1 and Table 1 can serve as a guide to the amount of damage to be expected under various conditions.

The great difference in the susceptibility of polyribonucleotides, compared with polydeoxynucleotides, to zinc cleavage makes possible the quantitative removal of RNA from a DNA-RNA mixture. This becomes evident when one calculates from the data of Table 1 that, at $50^{\circ} \mathrm{C}$ with zinc, about 5,000 breaks occur in a poly(rA) strand for one break in a DNA strand. Selective zinc degradation of RNA has already been utilised ${ }^{10}$ in connection with chromatin reconstitution studies; our results indicate that the DNA components remain intact during such degradation.

Our results suggest also that DNA should be much less susceptible than RNA to deleterious action by metal ions in vivo. Thus the question arises whether these effects may be part of the reason for the predominant evolutionary selection of DNA, instead of RNA, as the bearer of the primary genetic information.

Obviously, any attempt to answer this question, as any question involving evolutionary hypotheses, must be speculative. It has been suggested ${ }^{1}$ that the relatively small difference in thermal stability of DNA and RNA can account for the choice of the DNA duplex as the repository of genetic information. But this difference in thermal stability is only about one threehundredth the difference in stability to metal ions. Moreover, metal ion degradation of polyribonucleotides proceeds ${ }^{5}$ through a mechanism that involves the $2^{\prime} \mathrm{OH}$ group, the presence of which in RNA and absence in DNA constitutes the only primary structural difference between the two types of nucleic acid. For both of these reasons, if stability of the primary genetic material is a criterion of its evolutionary selection, susceptibility towards metal ions seems much more important than susceptibility towards heat. It is of course possible that evolutionary selection of the structure was in response to pressures other than stability and coincidentally resulted in DNA with high stability to metal ion degradation.

JAMES J. Butzow

GUNTHER L. EICHHORN

Laboratory of Molecular Aging,

Gerontology Research Center, National Institutes of Health, Baltimore City Hospitals, Baltimore, Maryland 21224

\footnotetext{
Received December 20, 1974.

1 Eigner, J., Boedtker, H., and Michaels, G., Biochim. biophys. Acta, 51, 165-168 (1961).

2 Eichhorn, G. L., and Butzow, J. J., Biopolymers, 3, 79-94 (1965).

3 Butzow, J. J., and Eichhorn, G. L., Biopolymers, 3, 95-107 (1965)

4 Eichhorn, G. L., Tarien, E., and Butzow, J. J., Biochemistry, 10, 2014-2019(1971).

5 Butzow, J. J., and Eichhorn, G. L., Biochemistry, 10, $2019-2027$ (1971).

Bamann, E., Trapmann, H., and Fischler, F., Biochem. Z., 326, 89-96 (1954).

7 Shin, Y. A., and Eichhorn, G. L., Biochemistry, 7, 1026-1032 (1968)

8 Felsenfeld, G., and Miles, H. T., A. Rev. Biochem., 36, 407-448 (1967).
9 Shin, Y. A., Heim, J. M., and Eichhorn, G. L., Bioinorg. Chem., 1, 149-163 (1972).

10 Huang, R. C., and Huang, P. C., J. molec. Biol., 39, 365-378 (1969).

12 Eichhorn, G. L., and Clark, P., Proc, natn. Acad. S

13 Fresco, J., and Doty, P., J. Am. chem. Soc., 79, 3928-3929 (1957)
}

\section{Amounts of isoaccepting lysine tRNAs change with the proliferative state of cells}

VARIATIONS in isoaccepting tRNA populations occur in mammalian cells during development, neoplasia, and virus infection, and such changes may reflect the involvement of tRNA in regulatory processes ${ }^{1,2}$, although firm evidence to that effect is not available. Ortwerth and $\mathrm{Liu}^{3}$ have shown that in normal or neoplastic cells an isoaccepting species of lysine tRNA, tRNA ${ }_{4}{ }^{\mathrm{Lys}}$, is present in dividing cells but absent from non-dividing cells. Ortwerth et al. ${ }^{4}$ determined some of the functional properties of $\mathrm{TRNA}_{4}{ }^{\mathrm{Ls}}$ from various tissues and obtained evidence that the species is a real isoacceptor of $\operatorname{tRNA}^{\mathrm{L} y \mathbf{s}}$ rather than an artefact. Normal, proliferating cells that were examined had only relatively small amounts of $\mathrm{tRNA}_{4}{ }^{\mathrm{Ls}}$; however, a larger proportion of the isoacceptor was found in neoplastic cells such as mouse leukaemia and Morris hepatoma cells. It is desirable, therefore, to establish whether the large amount of $\operatorname{tRNA}_{4}{ }^{\mathrm{L} y s}$ is peculiar to the neoplastic state or whether normal cells may also have large amounts of that isoacceptor under some growth conditions. Therefore, we studied isoaccepting lysyl-tRNA profiles from mouse cells in different states of proliferation: adult liver, embryo and growing and quiescent primary cultures of embryonic cells. We found that normal growing cells also have an appreciable amount of $\mathrm{tRNA}_{4}{ }^{\mathrm{L}}$ ss .

Ten-day-old mouse embryos, with heads and extremities removed, were prepared for monolayer tissue culture by dispersing cells with trypsin and seeding in roller bottles in Eagle's $\mathrm{MEM}^{5}$ containing penicillin $\mathrm{G}\left(100 \mathrm{U} \mathrm{ml}^{-1}\right)$, streptomycin $\left(100 \mu \mathrm{g} \mathrm{ml}^{-1}\right)$ and $10 \%$ foetal calf serum. tRNA and aminoacyltRNA ligases were isolated from primary cells, embryo and liver as previously described ${ }^{6}$ and tRNA was purifed further by DEAE-cellulose chromatography?. tRNA was aminoacylated with lysine as before ${ }^{8}$.

In mouse leukaemia cells in suspension culture, $\operatorname{tRNA}_{4}{ }^{\mathbf{l y s}}$ is $47 \%$ of the total tRNA ${ }^{\mathrm{Lys}}$, and this amount decreases to $16 \%$ as cell density increases and proliferation stops ${ }^{3}$. Comparable data on the amount of $\mathrm{tRNA}_{4}{ }^{\mathrm{L} \text { ys }}$ in a uniform population of rapidly dividing normal cells and the effect of increasing cell density were not available. We have compared the Lys-tRNA ${ }^{\text {Lys }}$ profiles of growing and density-inhibited quiescent primary cultures of embryonic cells. The results (Fig. 1a) indicate a much larger amount of $\mathrm{RNA}_{4}{ }^{\mathrm{L} y s}$ in growing cells than in resting cells. Consistent with these results is the finding of an appreciable amount of $\mathrm{TRNA}_{4}{ }^{\mathrm{L} y \mathrm{~s}}$ in embryonic cells which were not in tissue culture (Fig. $1 b$ ). These results also indicate that placing the cells in tissue culture does not in itself lead to an altered $\mathrm{TRNA}^{\mathrm{L} y \mathrm{~s}}$ profile. In contrast to results with proliferating cells, tRNA ${ }_{4}{ }^{\mathrm{L} y s}$ is present only in a very small amount in adult mouse liver (Fig. 1c).

The results are summarised in a quantitative manner in Table 1. tRNA $_{4}{ }^{\mathrm{L} y \mathrm{~s}}$ varies from $3 \%$ in adult mouse liver to $24 \%$ in proliferating monolayer culture. Similar results with cultured murine sarcoma virus-transformed cells (H. J., D. J., and C. H., unpublished) and SV40-transformed cells (J. Katze, personal communication) have been obtained. In toth cases, $\operatorname{tRNA}_{5 \mathrm{a}}{ }^{\mathrm{L} y \mathrm{~s}}$ (ref. 8) seems to be present in addition to $\mathrm{TRNA}_{4}{ }^{\mathrm{Lys}}$ in rapidly proliferating cells and decreases as the cell population becomes

Table 1 Effect of state of growth of cells on chromatographic distribution of isoacceptors of lysine tRNA

\begin{tabular}{|c|c|c|c|c|c|}
\hline \multirow[t]{2}{*}{ Cells } & \multirow[t]{2}{*}{$\begin{array}{l}\text { Growth } \\
\text { state }\end{array}$} & \multicolumn{4}{|c|}{$\begin{array}{l}\text { Distribution of lysine } \\
\text { tRNA isoacceptors }\end{array}$} \\
\hline & & 1 & 2 & 4 & \\
\hline Adult mouse liver & Quiescent & - & 58 & 3 & 38 \\
\hline Primary mouse embryo & Quiescent & 2 & 50 & 9 & 40 \\
\hline Mouse embryo & Growing & 4 & 37 & 15 & 44 \\
\hline Primary mouse embryo & Growing & 2 & 35 & 24 & 38 \\
\hline
\end{tabular}



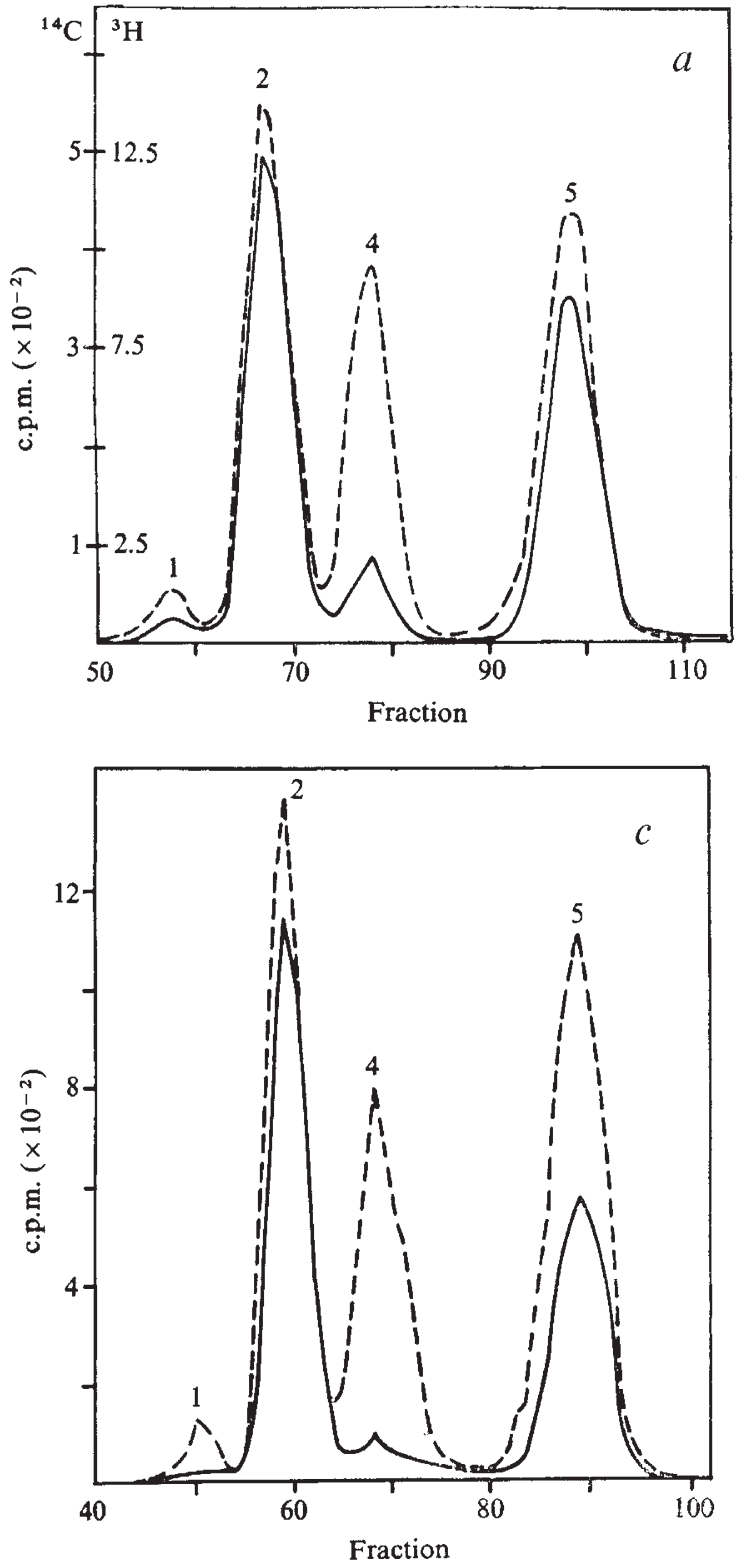

dense. (The presence of $\operatorname{tRNA}_{5 \mathrm{a}}{ }^{\mathrm{L} y \mathrm{~s}}$ is not always detected by RPC-5 chromatography, but benzoylated DEAE-cellulose chromatography provides resolution ${ }^{8}$.) The effect of cell density on profiles of other isoaccepting tRNAs has been noted ${ }^{10}$.

It is now clear that the distribution of isoaccepting species of tRNA $^{\mathrm{Lys}}$ in both normal and neoplastic cells varies with the proliferative state of cells. The constancy of the sum of percentages of $\mathrm{tRNA}_{2}{ }^{\mathrm{L} \text { ys }}$ and $\mathrm{tRNA}_{4}{ }^{\mathrm{L} y \mathrm{~s}}$ suggests that species 2 and 4 are structurally related with differences attributed to the degree of modification ${ }^{4}$. Confirmation of that possibility and investigations into functional differences are the subjects of continuing investigations.

This research was supported by grants from the US Public Health Service.

Department of Biochemistry,

Kansas State University,

Manhattan, Kansas 66506

HeCtor Juarez

DOLORES JUAREZ

Charles Hedgcoth

B. J. ORTWERTH

Departments of Biochemistry and Ophthalmology

University of Missouri Medical Center,

Columbia, Missouri 65201

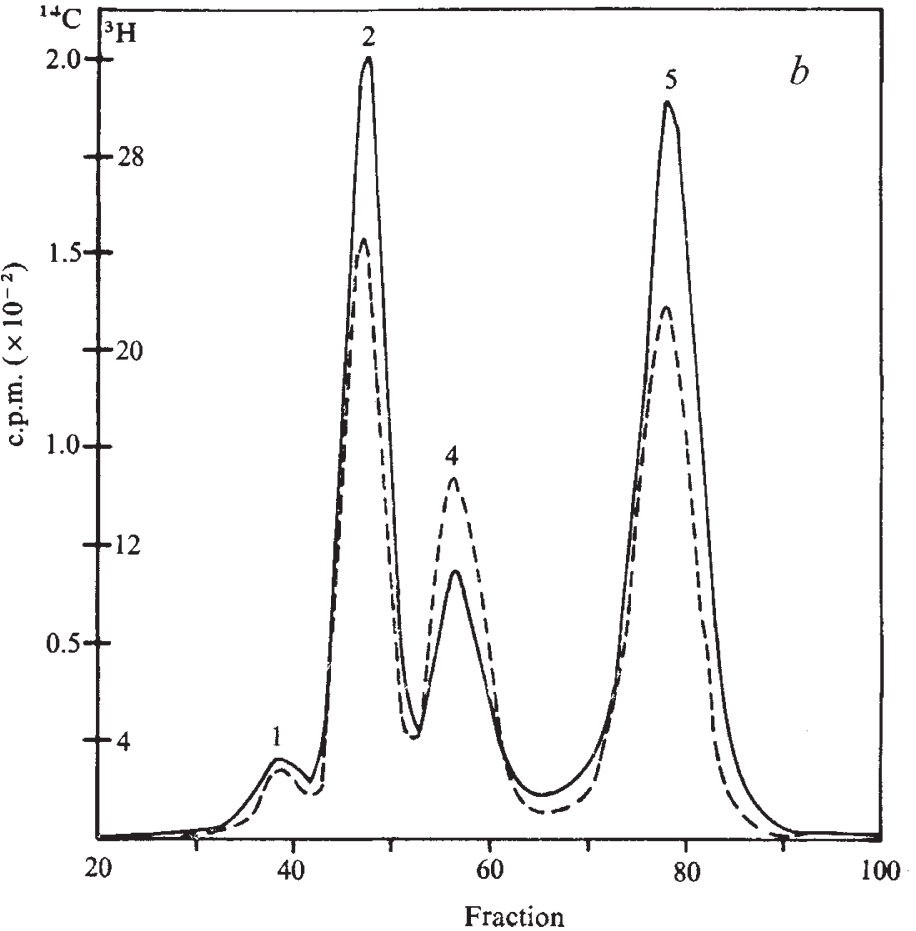

Fig. 1 Comparison of lysyl-tRNA from primary embryo cells in growing and quiescent states, from adult liver and from whole embryo. Growing primary cells were collected at $5.5 \times 10^{4}$ cells $\mathrm{cm}^{-2}$, and quiescent primary cells were collected $48 \mathrm{~h}$ later at $9.4 \times 10^{4}$ cells $\mathrm{cm}^{-2}$. The generation time for primary cultures of mouse embryo cells is about $18 \mathrm{~h}$. Lysyl-tRNA was chromatographed in the RPC-5 system ${ }^{9}$ on a $0.9 \times 100 \mathrm{~cm}$ column with a linear gradient $(500 \mathrm{ml})$ from 0.5 to $0.65 \mathrm{M} \mathrm{NaCl}$ in $10 \mathrm{mM}$ sodium acetate buffer, $p \mathrm{H} 5$, containing $10 \mathrm{mM}$ $\mathrm{MgCl}_{2}$. Fractions of $4 \mathrm{ml}$ were collected at a flow rate of $1.3 \mathrm{ml} \mathrm{min}-1$. Radioactivity in each fraction was determined in $15 \mathrm{ml}$ of a $2: 1$ mixture of toluene-base scintillation fluid and Triton X-100. $\operatorname{tRNA}_{3}{ }^{\mathrm{ys}}$ is a minor species and is not resolved in our system. $a$, Growing primary cells $\left(-\ldots,{ }^{3} \mathrm{H}\right)$ and quiescent primary cells $\left(-\frac{1}{14} \mathrm{C}\right) ; b$, growing primary cells $\left(\ldots,,{ }^{3} \mathrm{H}\right)$ and embryo $\left(-,{ }^{14} \mathrm{C}\right) ; c$, growing primary cells $\left(-\ldots,{ }^{3} \mathrm{H}\right)$ and liver $\left(-,{ }^{14} \mathrm{C}\right)$.

Received November 20, 1974; revised January 27, 1975.

1 Sueoka, N., and Kano-Sueoka, T., Prog. Nucleic Acid Res. molec. Biol., 10, $23-55(1970)$.

2 Littauer, U. Z., and Inouye, H., Ann. Rev. Biochem., 42, 439-470 (1973).

Ortwerth, B. J., and Liu, L. P., Biochemistry, 12, 3978-3984 (1973). Ortwerth,

Eagle, H., Science, 130, 432-437 (1959).

6 Jacobson, E. L. Juarez, H. Hedgcoth, C., and Consigli, R. A., Archs Biochem. Biophys 163, 666-670 (1974).

Yang, W.-K., and Novelli, G. D., Biochem. biophys. Res. Commun., 31, 534-539 (1968).

Juarez, H., Juarez, D., and Hedgcoth, C., Biochem. biophys. Res. Commun., 61, 100-116(1974).

Pearson, R. L., Weiss, J. F., and Kelmers, A. D., Biochim. biophys. Acta, 228, 770-774 (1971).

10 Katze, J., Biochim. biophys. Acta (in the press).

\section{Errata}

In the article "An ancient lunar magnetic dipole field" by S. K. Runcorn (Nature, 253, 701; 1975) the legends to Fig. $2 a$ and $b$ were transposed.

In the article "A gene cluster in Aspergillus nidulans with an internally located cis-acting regulatory region" by $\mathrm{H}$. N. Arst and D. W. MacDonald (Nature, 254, 26; 1975) there was an error in Fig. 1. The two arrows linking L-proline and $\mathrm{L}-\Delta^{1}$-pyrroline-5-carboxylate should be reversed-so that the top arrow points to the right and the bottom to the left. 